\title{
Mutagenicity of two species of the genus Alchornea measured by Salmonella microsome assay and micronucleus test
}

\author{
Fabio V. dos Santos, ${ }^{1}$ Tamara R. Calvo, ${ }^{2}$ Ilce Mara S. Cólus, ${ }^{3}$ Wagner Vilegas, ${ }^{2}$ \\ Eliana A. Varanda ${ }^{*}$,
}

\author{
${ }^{1}$ Faculty of Pharmaceutical Sciences, Department of Biological Sciences, São Paulo State University, Campus \\ Araraquara, Rodovia Araraquara-Jaú, km 1, 14801-902 Araraquara-SP, Brazil, \\ ${ }^{2}$ Organic Chemistry Department, Chemistry Institute, São Paulo State University, PO Box 355, 14800-900 \\ Araraquara-SP, Brazil, \\ ${ }^{3}$ Department of General Biology, Biological Sciences Center, Londrina State University, Londrina, PR, Brazil.
}

\begin{abstract}
RESUMO: "Mutagenicidade de duas espécies do gênero Alchornea avaliadas através de ensaios com Salmonella microssomo e teste do micronúcleo." Algumas espécies de plantas do gênero Alchornea (Euphorbiaceae) são conhecidas por apresentarem as atividades biológicas: antioxidante, antifúngica, antiinflamatória, antibacteriana, citotóxica para células tumorais e inibidoras da replicação dos vírus HIV-1 e HIV-2. São também amplamente usadas na medicina popular na America do Sul e África. No Brasil, Alchornea castaneaefolia Willd. A. Juss. e Alchornea glandulosa Poepp. \& Endl. são usadas para tratamento do reumatismo, artrite e dores musculares. Devido ao uso medicinal dessas plantas e o potencial risco do seu consumo indiscriminado, no presente trabalho foi avaliada a atividade mutagênica dos extratos metanólico e clorofórmico das folhas, empregando o teste do micronúcleo in vivo e o teste de Ames. Os resultados mostraram que o extrato clorofórmico não apresentou mutagenicidade, porém, o extrato metanólico de $A$. castaneaefolia foi mutagênico para a linhagem TA98 de Salmonella typhimurium e o extrato metanólico de $A$. glandulosa para as linhagens TA98 e TA97a. O extrato metanólico de ambas as espécies também apresentaram mutagenicidade positiva nos ensaios in vivo na maior concentração usada. Os prováveis agentes mutagênicos envolvidos foram a quercetina aglicona e amentoflavona presentes em ambas as espécies.
\end{abstract}

Unitermos: Alchornea, micronucleo, teste de Ames, mutagenicidade, planta medicinal.

\begin{abstract}
Some species of the plant genus Alchornea (family Euphorbiaceae) are widely used in popular medicine, mainly in South America and in Africa. Several kinds of biological activity have been seen in the species: antioxidant, antifungal, anti-inflammatory, antibacterial, cytotoxic against tumor cell lines and inhibitory to the replication of HIV-1 and HIV-2. In Brazil, the species Alchornea castaneaefolia Willd. A. Juss. and Alchornea glandulosa Poepp. \& Endl. are used by the local population to treat rheumatism, arthritis and muscular pains. In view of the popular use of these plants as medicines and the potential risks from their consumption, we assessed the mutagenic potential of chloroform and methanol extracts of the leaves of these plant species, employing the in vivo micronucleus test and the Ames assay. The data obtained showed that the chloroform extracts were not mutagenic. The methanol extract of $A$. castaneaefolia was mutagenic to strain TA98 of Salmonella typhimurium and the methanol extract of A. glandulosa to strains TA98 and TA97a. The methanol extracts of both species of Alchornea were mutagenic in vivo at the largest dose employed. The probable mutagenic agents involved were the aglycone quercetin and amentoflavone, present in both species.
\end{abstract}

Keywords: Alchornea, Micronucleus, Ames Assay, Mutagenicity, Medicinal Plant.

\section{INTRODUCTION}

The genus Alchornea belongs to the spurge family Euphorbiaceae, which contains about 7500 species in all parts of the world, including trees, shrubs and herbs. This family is economically important, providing food, rubber, medicines, oils, dyes and many other useful products (Duke \& Vaskez, 1994). The genus Alchornea is widely used in popular medicine, mainly in South America and Africa (Schwontkowski, 1993).

Several forms of biological activity have been described for species of this genus: antioxidant (Farombi 
et al., 2003), antifungal (Abo \& Ashidi, 1999), antiinflammatory (Osadebe \& Okoye, 2003), antibacterial, cytotoxic against tumor cell lines (Setzer et al., 2000) and inhibitory to the replication of HIV-1 and HIV-2 (Ayisi \& Nyadedzor, 2003). According to Lamikanra et al. (1990) and Ebi (2001), the species of the genus Alchornea possess alkaloids, flavonoids and terpenoids in their chemical constitution.

In the Brazilian "savannah", locally known as cerrado, two species of this genus are used by the local population in medical treatments. Alchornea castaneaefolia Willd. A. Juss. is a small tree or shrub of about 2-3 m, popularly known as "sarã" or "gurupiá" (Lorenzi, 2002). Parts of this plant are commonly use in the treatment of rheumatism, arthritis and muscular pains (Duke \& Vaskez, 1994). Methanol extract obtained from stem bark of this species exhibit anti-inflammatory activity in vitro and in vivo (Dunstan et al., 1997). One study showed antiinflammatory activity in an acetate fraction obtained from the methanol extract of the leaves of $A$. castaneaefolia (Lopes et al., 2005). Hiruma-Lima et al. (2006) showed that a compound obtained from this species had antiulcerogenic activity.

Alchornea glandulosa Poepp. \& Endl. is a 10$20 \mathrm{~m}$ high tree known popularly in Brazil as "tapiá" or "boleiro" (Lorenzi, 2002). According to Conegero et al. (2003) the leaves of this species are rich in phytosterols, terpenoids, alkaloids and, phenolic compounds and, according these authors, the methanol extract of these leaves have antimicrobial and antitumor activities.

In light of the popular use of these plant species in medicinal treatments and the possible risks involved in consuming them, in this study we assessed the mutagenic potential of extracts of the leaves of $A$. castaneaefolia and A. glandulosa employing the micronucleus test in vivo and the Salmonella mutagenicity assay (Ames Test). The leaves of these plants are used, commonly in infusion in folk medicine. This preparation type, extracts primarily polar compounds present in the composition of the medicinal plants. However, in this study we evaluated polar and apolar extracts to assess the risks of the variable types of compounds present in these plants to the human users. The identification of mutagenic compounds in phytochemical composition of medicinal plants permits to infer the risks inherent to the use of these natural compounds in traditional treatments.

\section{MATERIAL AND METHODS}

\section{Chemicals}

Dimethylsulfoxide, methanol, dichloromethane, nicotinamide adenine dinucleotide phosphate sodium salt, D-glucose-6-phosphate disodium salt, magnesium chloride, L-histidine monohydrate, D-biotin, sodium azide, 2-anthramine and 4 nitro-o-phenylenediamine were purchased from Sigma Chemical Co (St. Louis,USA). Oxoid Nutrient Broth No. 2 (Oxoid, England) and Difco Bacto Agar (Difco, USA) were used as bacterial media. D-Glucose, magnesium sulfate, citric acid monohydrate, potassium phosphate dibasic anhydrous, sodium ammonium phosphate, sodium phosphate monobasic, sodium phosphate dibasic and sodium chloride were purchase from Merck (Whitehouse Station, NJ).

\section{Vegetable material}

The leaves of $A$. castaneaefolia were collected by Dr. Clelia A. Hiruma Lima, in the town of Palmas (TO, Brazil) and identified by Dr. Solange de Fátima Lólis. A voucher specimen was deposited at the Tocantins State University Herbarium, with the number: TO4321. The leaves of A. glandulosa were collected by Tamara Regina Calvo and Luis Fernando Rolim in the town of Piracicaba (SP, Brazil) and the material was identified by Dr. Jorge Tamashiro. A voucher specimen was deposited at the Campinas State University Herbarium, with the number 132828.

Leaves of A. glandulosa (500 g) and of $A$. castaneaefolia $(400 \mathrm{~g})$ were air dried $\left(7\right.$ days at $\left.40{ }^{\circ} \mathrm{C}\right)$ and powdered. The powdered dried leaves were exhaustively extracted with chloroform and methanol successively at room temperature (three times, $48 \mathrm{~h}$ for each solvent). Extracts were filtered and solvents evaporated at $35^{\circ} \mathrm{C}$ under reduced pressure, affording chloroform $\left(\mathrm{ECHCl}_{3}\right)$ and methanolic $(\mathrm{EMeOH})$ solid extracts, respectively. The A. castaneaefolia yields $5.2 \mathrm{~g}(1.0 \%) \mathrm{ECHCl}_{3}$ and $7.5 \mathrm{~g}$ (1.5\%) EMeOH; the A. glandulosa yields $21 \mathrm{~g} \mathrm{(4.2 \% )}$ were $\mathrm{ECHCl}_{3}$ and $59 \mathrm{~g}(11.8 \%) \mathrm{EMeOH}$.

\section{Ames mutagenicity assay}

The Salmonella mutagenicity assay was performed by the preincubating test compounds for 20-30 min with the S. typhimurium strains TA98, TA100, TA97a and TA102, with or without metabolic activation (Maron \& Ames, 1983). The S9-mix was freshly prepared before each test with an Aroclor-1254-induced rat liver fraction purchased (lyophilized) from Moltox (Molecular Toxicology Inc.). $S$. typhimurium strains were kindly provided by Dr. B. Ames, University of California, Berkeley, CA, USA.

Various concentrations of the extracts of the leaves of A.castaneaefolia and A. glandulosa were assayed. All of them were diluted in dimethylsulfoxide (DMSO). The EMeOH of A. castaneaefolia was tested in concentrations of 3.63, 7.26, 14.52, 21.78 and $29.04 \mathrm{mg} /$ plate and the $\mathrm{ECHCl}_{3}$ in concentrations of 1.01, 2.02, 4.05, 6.08 and $8.10 \mathrm{mg} / \mathrm{plate}$. The $\mathrm{EMeOH}$ of $A$. glandulosa was tested at $2.83,5.67,11.35,17.02$ and $22.70 \mathrm{mg} /$ plate and the $\mathrm{ECHCl}_{3}$ at 1.74, 3.47, 6.95, 10.42 and $13.90 \mathrm{mg} /$ plate.

The concentrations used were based on the bacterial toxicity, in a preliminary test performed with 
strains TA98 and TA100. Toxicity was apparent either as a reduction in the number of his + revertants, or as an alteration in the auxotrophic background (i.e. background lawn).

The highest concentrations of all extracts assessed were chosen based in the solubility limits of these extracts in solvent used (DMSO) and in the limitation of the use of $100 \mu \mathrm{L}$ of DMSO per plate. Considering the relatively lower yield in extraction process described previously, the assessed concentrations are probably higher than that used in popular medicine.

The various amounts of tested compounds were added to $500 \mu \mathrm{L}$ of buffer $\mathrm{pH} 7.4$ and $100 \mu \mathrm{L}$ of bacterial culture and then incubated at $37{ }^{\circ} \mathrm{C}$ for $20-30 \mathrm{~min}$. After this time, $2 \mathrm{~mL}$ of top agar was added to the mixture and poured on to a plate containing minimal agar. The plates were incubated at $37^{\circ} \mathrm{C}$ for $48 \mathrm{~h}$ and the his + revertant colonies counted manually. The influence of metabolic activation was tested by adding $500 \mu \mathrm{L}$ of S9 mixture $(4 \%)$ in place of the buffer, before preincubation. All experiments were performed in triplicate.

The standard mutagens used as positive controls in experiments without S9 mix were 4-nitro- $O$ phenylenediamine $(10 \mu \mathrm{g} /$ plate $)$ for TA98 and TA97a, sodium azide $(1.25 \mu \mathrm{g} / \mathrm{plate})$ for TA100 and daunomycin (3 $\mu \mathrm{g} /$ plate) for TA102. 2-anthramine (1.25 $\mu \mathrm{g} /$ plate $)$ was used in the experiments with metabolic activation with all strains. DMSO served as the negative (solvent) control (100 $\mu \mathrm{L} /$ plate).

The counts of revertants were analyzed with Salanal statistical software. The mutagenicity index (MI) was also calculated for each dose. MI is the average number of revertants per plate divided by the average number of revertants per plate from the negative (solvent) control. A sample was considered positive when the MI $\geq 2$ for at least one of the tested doses and if it gave a reproducible dose-response curve (Varella et al., 2004; Santos et al., 2008). Extracts that presented concentrations that induces significant difference in comparison to negative control revertants frequency and MI higher than 1.5 and lower than 2 were considered as a weak mutagen (Mortelmans \& Zeiger, 2001).

\section{Micronucleus test}

Five to six-week old albino Swiss mice (Mus musculus), weighing approximately $30 \mathrm{~g}$, from the Central Animal Facility of Londrina State University (Parana, Brazil), were kept individually in polypropylene cages conforming to the conditions for animal care recommended by the Canadian Council on Animal Care (Olfert et al., 1993). Mice were divided into groups of ten (five males and five females) for each treatment. The animals were treated with $0.1 \mathrm{~mL}$ of each of the solutions tested per $10 \mathrm{~g}$ body weight and had free access to water and food throughout the treatment period. All the procedures were approved by the Ethics in Research Committee of the FCF-São Paulo State University at Araraquara (UNESP, SP, Brazil).

Owing to the negative results obtained with the chloroform extracts in the Salmonella tests and also to the low solubility of $\mathrm{ECHCl}_{3}$ in any of the solvents recommended for the animal treatment, only the $\mathrm{EMeOH}$ of A. castaneaefolia and A. glandulosa were evaluated in this test. The extracts were assessed in three different doses: $625.0,937.5$ and $1250.0 \mathrm{mg} / \mathrm{kg} \mathrm{b.w.,} \mathrm{administered}$ by gavage. These doses were based on the solubility limit of the extract in distilled water and no tested dose was toxic to the mice.

The micronucleus test on peripheral blood cells was carried out as described by Hayashi et al. (1990), who used slides prestained with acridine orange. Glass slides were heated to about $70^{\circ} \mathrm{C}$ on a hot-plate and a $10 \mu \mathrm{L}$ drop of an aqueous solution of the dye $(1 \mathrm{mg} / \mathrm{mL})$ was placed on each slide and spread evenly over the surface with the end of a second well-cleaned slide. Once dry, the slides were kept in the dark at room temperature for at least 24 h.

Thirty hours after the treatment of the animals their blood was sampled by perforating the caudal vein of the mouse with a needle and collecting $5 \mu \mathrm{L}$ drops, each of which was placed at the centre of a prestained slide and covered with a cover-slip ( $24 \times 40 \mathrm{~mm})$. These slides were then kept in the dark, at $-20{ }^{\circ} \mathrm{C}$, for a minimum of $24 \mathrm{~h}$, before cytological examination of the blood cells.

The cell preparations were examined under a fluorescence microscope (Nikon), with a blue (488 nm) excitation filter and yellow (515 nm) emission (barrier) filter, using an oil-immersion objective. One thousand reticulocytes per treated animal were analyzed and the proportion of micronucleated cells counted.

Negative and positive control groups were established, which were treated, respectively, with distilled water (via gavage) and cyclophosphamide (CP - $40 \mathrm{mg} / \mathrm{kg}$ b.w., i.p.).

For the statistical analysis, ANOVA was carried out, followed by the Tukey-Kramer test, to compare the results obtained for the groups treated with extract with the negative control group.

\section{RESULTS}

Table 1 shows the Ames test results for the $\mathrm{MeOH}$ and $\mathrm{CHCl}_{3}$ extracts of the leaves of $A$. castaneaefolia. The $\mathrm{ECHCl}_{3}$ was not mutagenic in vitro, but the highest concentration employed was cytotoxic to strain TA100 without metabolic activation (-S9). The $\mathrm{EMeOH}$ was mutagenic to strain TA98 (+S9/-S9).

The results of the Ames test performed with various concentrations of the $\mathrm{EMeOH}$ and $\mathrm{ECHCl}_{3}$ of $A$. glandulosa are given in Table 2. The $\mathrm{ECHCl}_{3}$ was not mutagenic, while the $\mathrm{EMeOH}$ was mutagenic to strains TA98 (+S9/-S9) and TA97a (-S9). However, this extract 
increased appreciably the basal number of revertants in the other strains used (the values of MI are around 2).

Table 3 shows the results obtained in the in vivo micronucleus assay. Only the $\mathrm{EMeOH}$ were evaluated.
The methanol extracts of the two plant species were both mutagenic in vivo. The highest tested doses of both extracts cause chromosomal damage in the mouse blood cells.

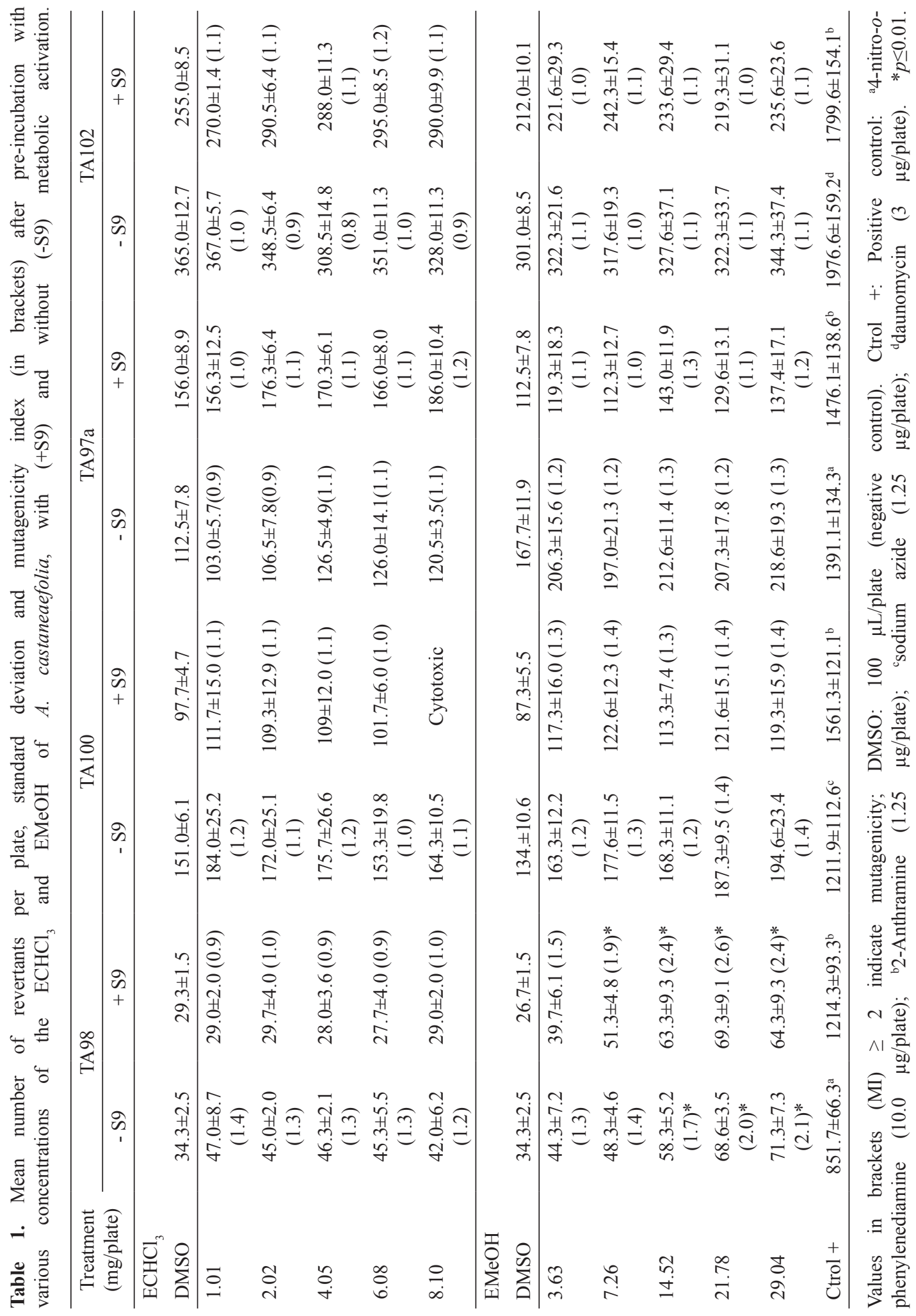




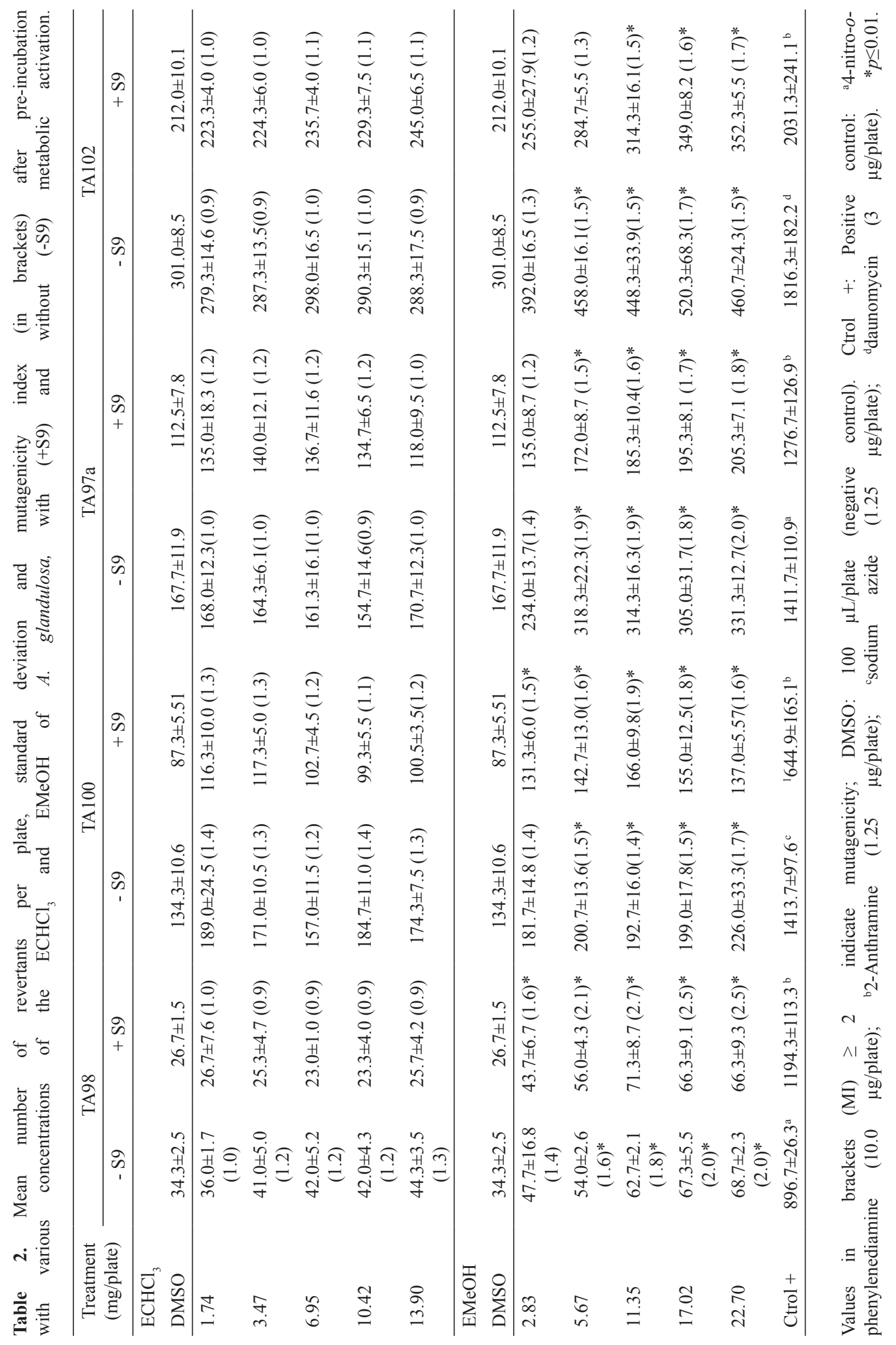


Table 3. Number of micronuclei per thousand mouse blood reticulocytes, mean and standard deviation, thirty hours after mice were treated with various doses of the methanol extract of A. castaneaefolia and A. glandulosa, by gavage.

\begin{tabular}{|c|c|c|c|c|c|c|c|c|c|c|c|c|}
\hline \multirow{2}{*}{$\begin{array}{c}\text { Treatment } \\
(\mathrm{mg} / \mathrm{kg} b . w .)\end{array}$} & \multicolumn{10}{|c|}{ Animals } & \multirow{2}{*}{ Mean } & \multirow{2}{*}{ SD } \\
\hline & 1 & 2 & 3 & 4 & 5 & 6 & 7 & 8 & 9 & 10 & & \\
\hline Cyclophosphamide & 22 & ND & 17 & 18 & 20 & 18 & 18 & 22 & 20 & 19 & $19.33^{*}$ & 1.80 \\
\hline Water & 2 & 1 & 1 & 3 & 1 & 2 & 1 & 2 & 1 & 0 & 1.40 & 0.84 \\
\hline \multicolumn{13}{|l|}{$\begin{array}{c}\text { Alchornea } \\
\text { castaneaefolia }\end{array}$} \\
\hline 625 & 3 & 2 & 2 & 3 & 1 & 2 & 3 & 3 & 2 & 2 & 2.30 & 0.67 \\
\hline 937.5 & 2 & 3 & 2 & 4 & 1 & 2 & 3 & 2 & 3 & 1 & 2.30 & 0.95 \\
\hline 1250 & 4 & 6 & 3 & 4 & 5 & 5 & 5 & 4 & 4 & 4 & $4.40 *$ & 0.84 \\
\hline \multicolumn{13}{|l|}{$\begin{array}{l}\text { Alchornea } \\
\text { glandulosa }\end{array}$} \\
\hline 625 & 1 & 0 & 2 & 1 & 3 & 1 & 2 & 2 & 1 & 1 & 1.40 & 0.84 \\
\hline 937.5 & 2 & 2 & 1 & 1 & 2 & 3 & 2 & 4 & 2 & 1 & 2.00 & 0.94 \\
\hline 1250 & 4 & 3 & 5 & 4 & 5 & 6 & 4 & 4 & 3 & 4 & $4.20 *$ & 0.92 \\
\hline
\end{tabular}

Cyclophosphamide: Positive Control (40 mg/kg bw); Water: Negative Control; Animals 1-5: Males; Animals 6-10: Females; SD: Standard Deviation; ND: Not Determined; *Statistically different from the Negative Control.

\section{DISCUSSION}

The mutagenicity of the leaf extracts in $\mathrm{CHCl}_{3}$ and $\mathrm{MeOH}$ of A. castaneaefolia and A. glandulosa was assessed in vivo by the Micronucleus Assay and in vitro by the Ames Assay.

The $\mathrm{CHCl}_{3}$ extracts $\left(\mathrm{ECHCL}_{3}\right)$ of the $A$. castaneaefolia and A. glandulosa were not mutagenic under the conditions employed. In this extract were identified the steroids stigmasterol, campesterol and $\beta$-sitosterol. According to Kritchevsky \& Chen (2005) these steroids are widelly distributed in nature. Wolfreys and Hepburn (2002) show that these compounds do not caused DNA damage in a study employing different analysis systems in vivo and in vitro. These information reinforce the negative results obtained in Ames Assay to the chloroform extracts assessed.

The $\mathrm{MeOH}$ extract $(\mathrm{EMeOH})$ of $A$. glandulosa was mutagenic to the strains TA98 and TA97a. In the other strains, this extract promoted statistically significant rises in the revertant frequency, but the MIs were lower than 2, with or without $\mathrm{S} 9$ fraction. The $\mathrm{EMeOH}$ of $A$. castaneaefolia caused statistically significant alterations only to TA98 (-S9/+S9), with mutagenicity index higher than 2.

These results indicate that the $\mathrm{EMeOH}$ of these species have in their constitution compounds that cause frameshift mutations, directly or after metabolic activation, since the revertants of TA98 and TA97a are specific to compounds with this mechanism of action.

Conegero et al. (2003) showed the presence of a mixture of $\beta$-sitosterol and stigmasterol, the terpenoid loliolide, the guanidine alkaloid $\mathrm{N}-1, \mathrm{~N}-2, \mathrm{~N}-$ 3 -triisopentenylguanidine and the phenolic compound corilagin in the leaves of A. glandulosa. In addition, according to Calvo et al. (2007), quercetin-3-O- $\beta$-Dgalactopyranoside, quercetin-3- $O-\alpha$-L-arabinopyranoside, quercetin,myricetin-3-O- $\alpha$-L-rhamnopyranoside, amentoflavone, gallic acid, methylgallate and pterogynidine were all isolated from the $\mathrm{EMeOH}$ of $A$. glandulosa, leaves and identified.

Hiruma-Lima et al., (2006) isolated and identified quercetin-3-O- $\beta$-D-galactopyranoside, quercetin-3-O$\alpha$-L-arabinopyranoside, quercetin, myricetin-3-O- $\alpha$-Larabinopyranoside, amentoflavone, gallic acid and methyl gallate, besides glycolipids and free sugars, from an hydroalcoholic extract of $A$. castaneaefolia. These authors performed a comparative analysis of the hydroalcoholic extract and methanolic extract of $A$. castaneaefolia by HPLC-UV-PDA (RP-18, $250 \times 4.6 \mathrm{~mm}$ i.d., $5 \mu \mathrm{m}$, elution gradient $25-35 \%$ acetonitrile/water in $30 \mathrm{~min}$, flow rate 1.0 $\mathrm{mL} / \mathrm{min}$, detection $254 \mathrm{~nm}$ ) indicated the presence of the same compounds.

This chemical composition can explain the mutagenicity of the extracts detected by the Ames Assay. Several studies have shown that phenolic compounds can damage DNA (Jurado et al., 1991; Gaspar et al., 1993; Labieniec et al., 2003). According to Cardoso et al. (2006), the aglycone quercetin and amentoflavone were mutagenic to strain TA98, with and without metabolic activation. Uddin et al. (2004) showed that the amentoflavone, in the presence of copper ions, can damage DNA and give rise to reactive oxygen species.

According to MacGregor (1986), quercetin causes frameshift and base substitution mutations, and Gaspar et al. (1993) consider it responsible for the mutagenic activity of red wine. This activity said to derive from the generation of reactive oxygen species (ROS) by autooxidation.

However, the glycosylated derivates of quercetin do not show the mutagenicity described for the aglycone 
(Cardoso et al., 2006). According to Heim et al. (2002), the reactivity of flavonoids is directly related to their molecular structure. They affirm that the presence of several hydroxyl groups, of an unsaturated 2-3 bond conjugated with a 4-oxo function and the absence of carbohydrate moieties all enhance the activity of the molecule. This could explain the pro-oxidant activity of quercetin and amentoflavone.

Martinez et al. (2000) found that gallic acid could cause oxidative DNA damage but that this activity was reduced after the addition of S9 mix. However, Chen \& Chung (2000) affirmed that this compound was not mutagenic in the Ames Assay.

The guanidine alkaloid $N-1, N-2, N-3-$ triisopentenylguanidine, found in species of this genus Alchornea is highly cytotoxic in both tumor and normal cell cultures (Mavar-Manga et al., 2006). The tannin corilagin, according to Kinoshita et al. (2007), shows antioxidant activity and is able to reduce induced apoptosis in liver.

According to Kritchevsky \& Chen (2005), the phytosterols isolated from these Alchornea species are among the commonest in nature and they claim that these substances can act as controllers of the cholesterol levels in the blood. Awad \& Fink (2000) have related them to the prevention of several types of cancer. Wolfreys \& Hepburn (2002), in a study with these compounds, showed that they do not cause genetic damage in vitro or in vivo.

The mutagenicity in vivo of the methanol extracts of $A$. castaneaefolia and A. glandulosa was evaluated in mice, employing the micronucleus test in peripheral blood cells. Both extracts significantly altered the micronucleated cell frequency in mice treated by gavage. This reveals the presence of compounds that cause breaks in DNA and/or loss of whole chromosomes due to fails in mitotic fuse function.

Silva et al. (2002) assessed the aglycone quercetin, in high doses, employing the micronucleus test and the comet assay, and found that it causes DNA damage in vivo. Nevertheless, the activity observed in our tests could be caused by other compounds in the extracts and/or by the products of animal metabolism of these substances.

Based on the results presented in this paper, we conclude that compounds present in the methanol extracts of the leaves of $A$. castaneaefolia and A. glandulosa cause frameshift mutations in vitro (Ames Assay) and breaks and/or loss of whole chromosomes in vivo (Micronucleus Assay). Candidate mutagenic agents that probably contribute to this activity are the aglycone quercetin and amentoflavone, which are present in both species and whose mutagenicity is confirmed by the recent scientific literature. The inter-specific differences observed are probably due to variations in the proportions of these compounds in the extracts.

Mutational events can represent serious risks to human health. Mutations are involved in the initial steps of degenerative diseases such as cancer. Thus, the results reported here underline the risks of the indiscriminate use of natural compounds and the importance of research on the genotoxicity/mutagenicity of compounds obtained from plants, especially those used in popular medicine or as food.

\section{ACKNOWLEDGEMENTS}

We are grateful to the Fundação de Amparo à Pesquisa do Estado de São Paulo (FAPESP) for funding from the Biota-Fapesp Program and to the Conselho Nacional de Desenvolvimento Científico Tecnológico (CNPq) for a grant to F.V.S., E.A.V. and W.V.

\section{REFERENCES}

Abo KA, Ashidi JS 1999. Antimicrobial screening of Bridelia micrantha, Alchornea cordifolia and Boerhavia diffusa. Afr J Medicine Med Sci 28: 167-169.

Ayisi NK, Nyadedzor C 2003. Comparative in vitro effects of AZT and extracts of Ocimum gratissimum, Ficus polita, Clausena anisata, Alchornea cordifolia and Elaeophorbia drupifera against HIV-1 and HIV-2 infections. Antiviral Res 58: 25-33.

Awad AB, Fink CS 2000. Phytosterols as anticancer dietary components: Evidence and mechanism of action. J Nutr 130: 2127-2130.

Calvo TR, Lima ZP, Silva JS, Ballesteros KVR, Pellizzon $\mathrm{CH}$, Hiruma-Lima CA, Tamashiro J, Souza-Brito A.M, Takahira RK, Vilegas W 2007. Constituents and antiulcer effect of Alchornea glandulosa: activation of cell proliferation in gastric mucosa during the healing process. Biol Pharm Bull 30: 451-459.

Cardoso CRP, Cólus IMS, Bernardi CC, Sannomiya M, Vilegas W, Varanda EA 2006. Mutagenic activity promoted by amentoflavone and methanolic extract of Byrsonima crassa Niedenzu. Toxicology 225: 55-63.

Chen SC, Chung KT 2000. Mutagenicity and antimutagenicity studies of tannic acid and its related compounds. Food Chem Toxicol 38: 1-5.

Conegero LS, Ide RM, Nazari AS, Sarragiotto MH, Filho, BPD, Nakamura CV, Carvalho JE, Foglio MA 2003. Constituintes químicos de Alchornea glandulosa (Euphorbiaceae). Quim Nova 26: 825-827.

Duke J, Vasquez R 1994. Amazonian ethnobotanical dictionary. CRC Press Inc, Boca Raton, p. 677.

Dunstan CA, Noreen Y, Serrano G, Cox PA, Pereira P, Bohlin L 1997. Evaluation of some Peruvian medicinal plants by prostaglandin biosynthesis and rat ear edema assays. $J$ Ethnopharmacol 57: 35-56.

Ebi GC 2001. Antimicrobial activities of Alchornea cordifolia. Fitoterapia 72: 69-72.

Farombi EO, Ogundipe OO, Uhunwangho ES, Adeyanju MA, Moody JO 2003. Antioxidant properties of extracts from Alchornea laxiflora (Benth) Pax and Hoffman. Phytotherapy Res 17: 713-716.

Gaspar J, Laires A, Monteiro M, Laureano O, Ramos E, Rueff $\mathrm{J}$ 1993. Quercetin and the mutagenicity of wines. Mutagenesis 8: 51-55.

Hayashi M, Morita T, Kodama Y, Sofuni T, Ishidate Jr M 1990. The micronucleus assay with mouse peripheral blood reticulocytes using acridine orange-coated slides. Mutat 
Res 245: 245-249.

Heim KE, Tagliaferro AR, Bobilya DJ 2002. Flavonoid antioxidants: Chemistry, metabolism and structureactivity relationships. $J$ Nutr Biochem 13: 572-584.

Hiruma-LimaCA, Calvo TR, Rodrigues CM,AndradeFDP, Vilegas W, Souza-Brito ARM 2006. Antiulcerogenic activity of Alchornea castaneaefolia: Effects on somatostatin, gastrin and prostaglandin. J Ethnopharmacol 104: 215224.

Jurado J, Alejandre-Durán E, Alonso-Moraga A, Pueyo C 1991. Study on the mutagenic activity of 13 bioflavonoids with the Salmonella ara test. Mutagenesis 6: 289-295.

Kinoshita S, Inoue Y, Nakama S, Ichiba T, Aniya Y 2007. Antioxidant and hepatoprotective actions of medicinal herb, Terminalia catappa L. from Okinawa Island and its tannin corilagin. Phytomedicine 14: 755-762.

Kritchevsk D, Chen SC 2005. Phytosterols - health benefits and potential concerns: A review. Nutr Res 25: 413-428.

Labieniec M, Gabryelak T, Falcioni G 2003. Antioxidant and pro-oxidant effects of tannins in digestive cells of the freshwater mussel unio tumidus. Mutat Res 539: 19-28.

Lamikanra A, Ogundaini AO, Ogungbamila FO 1990. Antibacterial constituents of Alchornea cordifolia leaves. Phytotherapy Res 4: 198-200.

Lopes FC, Calvo TR, Vilegas W, Carlos IZ 2005. Inhibition of hydrogen peroxide, nitric oxide and TNF- $\alpha$ production in peritoneal macrophages by ethyl acetate fraction from Alchornea glandulosa. Biol Pharm Bull 28: 1726-1730.

Lorenzi H 2002. Árvores Brasileiras: Manual de identificação e cultivo de plantas arbóreas nativas do Brasil. Instituto Plantarum, Nova Odessa, p. 352

MacGregor JT 1986. Mutagenic and carcinogenic effects of flavonoids. In: Cody V, Middlenton E, Harbone B (Eds.), Plant Flavonoids in Biology and Medicine. Biochemical Pharmacological and Structure-Activity Relationships, Alan R. Liss, New York, pp. 411-424.

Maron DM, Ames BN 1983. Revised methods for the Salmonella mutagenicity test. Mutat Res 113: 173-215.

Martínez A, Urios A, Blanco M 2000. Mutagenicity of 80 chemicals in Escherichia coli tester strains IC203, deficient in oxyR, and its oxyRQ parent WP2 uvra/ pkm101: Detection of 31 oxidative mutagens. Mutat Res 467: 41-53.

Mavar-Manga H, Chapon D, Hoet S, Block S, Pauw-Gillet M, Quetin-Leclercq J 2006. N1,N2,N3-Trisisopentenyl guanidine and N1,N2-diisopentenyl guanidine, two cytotoxic alkaloids from Alchornea cordifolia (Schumach.\& Thonn.) Müll. Arg. (Euphorbiaceae) root barks. Nat Prod Comm 12: 1097-1100.

Mortelmans K, Zeiger E 2000. The Ames Salmonella/microsome mutagenicity assay. Mutat Res 455: 29-60.

Olfert ED, Cross, BM, McWilliam AA 1993. The Guide to the Care and Use of Experimental Animals. V. 1. Canadian Council on Animal Care, Ontario.

Osadebe PO, Okoye EC 2003. Anti-inflammatory effects of crude methanolic extract and fractions of Alchornea cordifolia. J Ethnopharmacol 89: 19-24.

Santos FV, Tubaldini,F., Cólus IMS, Andreo MA, Bauab TM, Leite CQ., Vilegas W, Varanda EA 2008. Mutagenicity of Mouriri pusa Gardner and Mouriri elliptica Martius. Food Chem Toxicol 46: 2721-2727.

Schwontkowski D 1993. Herbs of the amazon: traditional and common uses. Science Student Brain Trust Publishing,
Utah, p. 26.

Setzer WN, Shen X, Bates R., Burns JR, Mcclure KJ, Zhang P, Moriarity DM, Lawton RO 2000. A phytochemical investigation of Alchornea latifolia. Fitoterapia 71: 195198.

Silva JD, Herrmann SM, Heuser V, Peres W, Marronid NP, González-Gallego J, Erdtmann B 2002. Evaluation of the genotoxic effect of rutin and quercetin by comet assay and micronucleus test. Food Chem Toxicol 40: 941-947.

Uddin Q, Malik A, Azam S, Hadi N, Azmi AS, Parveen N, Khan NU, Hadi SM 2004. The biflavonoid, amentoflavone degrades DNA in the presence of copper ions. Toxicology in Vitro 18: 435-440.

Varella SD, Pozetti GL, Vilegas W, Varanda EA 2004. Mutagenic activity in waste from an aluminum products factory in Salmonella/microsome assay. Toxicol in Vitro 18: 895900.

Wolfreys AM, Hepburn PA 2002. Safety evaluation of phytosterol esters. Part 7. Assessment of mutagenic activity of phytosterols, phytosterol esters and the cholesterol derivative, 4-cholesten-3-one. Food Chem Toxicol 40: 461-470. 